\title{
Effect of composting of palm oil mill wastes and cow dung or poultry manure on Amaranthus hybridus growth and yield
}

\author{
${ }^{*}$ T.W. KOURA ${ }^{1,2}$, G.D. DAGBENONBAKIN 3 , V. M. KINDOMIHOU1,2, B. A. SINSIN1,2, \\ ${ }^{1}$ Laboratory of Ecology Applied, Faculty of Agronomics Sciences, University of Abomey Calavi, 04 BP 0004 \\ Cotonou Benin Republic, thalia052002@gmail.com; bsinsin@gmail.com http://www.leabenin-fsauac.net, (+229) \\ 97171859, (+229) 94938387 \\ ${ }^{2}$ Animal Production Department, Faculty of Agronomics Sciences, University of Abomey Calavi, 05 BP 0325 Cotonou \\ Benin Republic, vkindomihou@yahoo.fr \\ ${ }^{3}$ Agronomy section, Communication and Documentation in Agriculture Center of Cotton and Fibre Researches, \\ National Institute for Agricultural Research, Benin. 01BP:5078 Cotonou Benin Republic, dagust63@yahoo.fr \\ *corresponding author: thalia052002@gmail.com
}

Original submitted in on $1^{\text {st }}$ December 2014. Published online at www.m.elewa.org on 28 $8^{\text {th }}$ February 2015 http://dx.doi.org/10.4314/jab.v86i1.1

\begin{abstract}
SUMMARY
Objective: To evaluate the effect of shelter and different type of manure on degradation of palm oil mills wastes during composting and on growth and yield of African spinach (Amaranthus hybridus) grown on acrisol .

Methodology and results: Palm oil mills wastes were composted, with poultry manure or cow dung with and without shelter. The experimental trials used the split-split plot design with composting method as a principal factor, the types of manure and rates of compost as secondary factors. The composting of these wastes with manure under shelter improved their decomposition significantly. The compost made with poultry manure under shelter gave the highest plant growth and yield. The compost application rate of 20 t/ha was not enough to increase plant growth but increased its yield (20.1t/ha versus 17.9 t/ha).

Conclusion and application of findings: Palm oils mills waste can be composted and used to grow Amaranthus hybridus. However, it is better to compost these wastes with poultry manure than cow dung under shelter. In addition, farmers need to apply at least 20t/ha to have high yields.
\end{abstract}

KEY WORDS: acrisol; African spinach; Guinean climate; manure; shelter,

\section{INTRODUCTION}

Traditional vegetables offer a potential to diversify food sources among both rural and urban communities, resulting in household food security (Maroyi, 2011). One of these vegetables is Amaranthus hybridus. This vegetable, second most produced leafy vegetable and consumed in the southern Benin Republic (Assogba komlan et al.,
2007), is an important source of nutrients for healthy body growth and subsistence (Bailey, 1992). To cut fertilizers cost, estimated at least at $27 \%$ of productions charges (Assogba-Komlan, 2001; Makinde et al., 2010) and produce safe food, many researchers have been made on the use of organic wastes and farmyard manures in agriculture directly 
or through composting. According to Adewale (2011), composting in developing countries remains the most economical and efficient management technique of wastes. Palm oil mill wastes (POMW) management is a growing problem in palm oil producing countries. Using it as fuel is not environmentally sound and alternative methods as farm input are to be sought (Kolade et al., 2005). In palm oil producing countries, except Benin, many researches were conducted on composting of empty fruit bunches, fibre and palm oil mills effluents, which contain appreciable amounts of plants nutrients

\section{MATERIAL AND METHOD}

Experimental site: The experiment was conducted in one palm oil mill, "Ets GBEMAWONMEDE" farm in Sakete district of Plateau department in southern Benin republic. This farm transformed $1100 t$ of nuts per year into $198 \mathrm{t}$ of palm oil. The site is located between latitude $6^{\circ} 44^{\prime} 11^{\prime \prime} \mathrm{N}$ and $2^{\circ} 39^{\prime} 29^{\prime \prime} \mathrm{E}$. The area is in the Guinean climate with two rain seasons and two dry seasons. It receives an average annual precipitation of 1100 to 1200 $\mathrm{mm}$. The monthly rain quantity in two rain seasons from March to July and September to October with largest quantity of $169.56 \mathrm{~mm}$ and $161.44 \mathrm{~mm}$ rain water in June and October during season 1 and season 2. The experiments were carried out from July to September 2012. During the experiment, there was $77.5 \mathrm{~mm}$ of rain during six weeks after transplantation.

Composting process: Composting was carried out using combinations of composting method (no shelter and shelter) and type of manure added for POMW composting. There were three treatments in each compost method group:

$\mathrm{T}_{1}=$ Empty fruit bunches (EFB) (65\%) + fibre (35\%);

$\mathrm{T}_{2}=$ Empty fruit bunches $(50.4 \%)+$ fibre $(27.1 \%)+$ Poultry manure $(22.5 \%)$ and

$\mathrm{T}_{3}=$ empty fruit bunches $(50.4 \%)+$ fibre $(27.1 \%)+$ cow dung (22.5\%).

The composting was carried out using boxes of $3 \mathrm{~m} \times 2 \mathrm{~m}$ $x 1 \mathrm{~m}$ made with palm oil branches. The bottom of each box was covered with non-permeable membrane and the top was covered at $1.5 \mathrm{~m}$ from the heap top with semi permeable membrane. The amount of waste in each basket was 2.8 tons. The composting was carried out for 172 days. At two days intervals, temperatures of the contents were measured. To facilitate optimal aeration of the compost mixtures, the compost heaps were turned at day 29, 64, 92 and 118. At the end of the composting,
(Habib et al., 1997; Muhrizal et al., 2006; Schuchardt et al., 2008; Iwara et al., 2011; Embrandiri et al., 2013). Oil palm is a cash crop in Southern Benin that is grown by many families and plays a socio cultural role (Adegbola et al., 2009). POMW is available and can be used in organic production of Amaranthus hybridus. However, POMW needs to be composted in an open system and effect of shelter is analyzed (Shuaimi \& Ong, 2001). In addition, it is important to appreciate the real benefit of manure incorporation in POMW during their composting through Amaranthus hybridus growth and yield.

final composts, samples were collected for dry weights and chemical composition.

Experimental soil analysis: Soils samples were randomly taken at the surface $(0-15 \mathrm{~cm})$ and physicochemical properties were determined using standard procedures in Laboratory of Soil Science (LSS) of Faculty of Agronomic of Abomey-Calavi University. pH was determined using the potentiometric method with a pH meter. Total nitrogen was determined using kjeldahl method. Organic matter was determined with incineration method and carbon content was accessed though the formula: Carbon Content= Organic Matter/1.724. Metson method was used to evaluate CEC and Spectrophotometer of Atomic Absorption (SAA) for calcium, magnesium and potassium content determination in soil. Phosphorus was determined with Bray I method. The results of the soil analysis revealed a sandy soil, relatively acid $\left(\mathrm{pH}\left(\mathrm{H}_{2} \mathrm{O}\right)=6.4, \mathrm{pH}(\mathrm{KCl})=6.2\right)$, poor in nitrogen $(0.1 \%)$ but with appreciable exchangeable bases (13.38 meq/100g), phosphorus (72.41 p.p.m) and potassium (1.14 meq/100g). C/N mass ratio is 12.6 .

Plant material and Experimental design: The local Amaranthus hybridus seed was used. Seeds were obtained from Horticulture Center of Porto Novo in Benin. They were germinated and transplanted 24 days after sowing. From composting, six of composts were obtained:

- $\quad$ Compost $\mathrm{C} 1$ made with EFB and Fibre in opened boxes

- $\quad$ Compost C2 made with EFB and Fibre and Poultry manure in opened boxes

- $\quad$ Compost C3 made with EFB and Fibre and Cow dung in opened boxes 


\section{Koura et al. J. Appl. Biosci. Effect of composting of palm oil mill wastes and cow dung or poultry manure on Amaranthus hybridus growth and yield}

- $\quad$ Compost C4 made with EFB and Fibre in under shelter boxes

- $\quad$ Compost C5 made with EFB and Fibre and Poultry manure in under shelter boxes

- $\quad$ Compost C6 made with EFB and Fibre and Cow dung in under shelter boxes

The experiment was laid out as split plit plot arrangement fitted into a randomized complete block design with four replications. The main factor is the composting method with two variants (without cover and with cover) and the two second factors are respectively the type of manure (no manure, poultry manure, cow dung) and rates composts (0t/ha, 5t/ha, 10t/ha, 20t/ha). The experiment area was $39.5 \mathrm{~m} \times 25 \mathrm{~m}\left(987 \mathrm{~m}^{2}\right)$. The experimental plot size was $1 \mathrm{~m} \times 1 \mathrm{~m}$ with 0.5 and $1 \mathrm{~m}$ between the plots and replicates respectively. The trial was repeated 3 times with one week between two trials installation dates. Plant spacing was $0.2 \mathrm{~m} \times 0.2 \mathrm{~m}$. The composts quantities applied depending on their dry matter and were mixed with the topsoil. The plots were watered twice a day. Plants were treated with neem cake extract $(250 \mathrm{~g}$ mixed

\section{RESULTS}

Change during composting: The chemical composition of the raw materials used in the experiment is given in Table 1. EFB and cow dung used in this study contained a lot of water than others materials. EFB was very much rich in nitrogen and potassium. Only Fibre and cow dung contain large amount of potassium. The temperature trends during the process of composting are shown in Figure 1. The temperature increases $\left(48^{\circ} \mathrm{C}\right.$ to $\left.50^{\circ} \mathrm{C}\right)$ during the first twenty days before decreasing. The heaps returning allow new temperature increase. The increase of temperature reveals microorganisms' activities that corresponding to thermophile phase. The maximum temperature was reached after the first heap returning $\left(55^{\circ} \mathrm{C}\right)$ for composts were made under shelter while those made without shelter was reached after the second heap returning. After the fourth heap returning, the compost has begun the maturation phase. In the composting made under shelter $(\mathrm{C} 4, \mathrm{C} 5$, and $\mathrm{C} 6)$ as those where manure with $20 \mathrm{~L}$ of water left for one night) against $P$ sara basalis and Tetranychus spp. It had been done twice in the $2^{\text {nd }}$ and $3^{\text {rd }}$ weeks after transplanting.

Data Collection and analysis: Five plants selected randomly at the middle of each plot were marked and their heights, number of leaves, stem diameter were measured weekly. Heights were measured with decametre and ruler and stem diameter with veneer clapper. Four weeks after transplanting, marketable yield was assessed. For all growth variables (leaf number, height and stem girth), four ways ANOVA with composting method (2 levels), type of manure (3 levels), composts rates (4 levels) and Weeks after transplantation (5 levels) of variance were applied. For marketable yield, three ways ANOVA was used with the same factors except weeks after transplantation. To separate the 4 compost rates at each week, one way ANOVA was used. All these analyses were followed by Newman-keuls posthoc multiple comparison test at $5 \%$ probability. The analysis was done using SAS Vs 6 software.

was incorporated more increase of temperature was registered, so much microorganisms activities and waste decomposition resulted. The quality of the finished composts was assessed by following the nutrient levels, $\mathrm{C} / \mathrm{N}$ ratio, moisture level and texture. Except for compost $\mathrm{C} 1$, the values were within the acceptable limits (Table 2). The compost made from POMW and poultry manure under shelter showed higher nitrogen, phosphorus and calcium levels. Compared to composts made under shelter (C4, C5 and C6), composts made without shelter were slightly acid, poor in nitrogen, phosphorus, manganese and calcium, rich in potassium and carbon. In addition, compost obtained with poultry manure incorporation (C2 and $\mathrm{C5}$ ) are richer in nitrogen and phosphorus than those made without manure. Composts made with no manure are richer in potassium and Magnesium than those made with manure.

Table 1: Physico-chemical characteristics of raw materials

\begin{tabular}{lllll}
\hline Parameters & EFB & Fibre & Poultry manure & Cow dung \\
\hline Moisture $(\%)$ & 67.17 & 31.17 & 29.28 & 49.5 \\
$\mathrm{C}(\%)$ & 44.24 & 47.78 & 6.68 & 12.76 \\
$\mathrm{~N}(\%)$ & 1.6 & 0.95 & 0.86 & 1.23 \\
$\mathrm{~K}(\mathrm{mg} / \mathrm{g})$ & 165.5 & 46.08 & 3.01 & 6.12 \\
$\mathrm{P}(\mathrm{mg} / \mathrm{g})$ & 0.01 & 1.72 & 0.2 & 1.47 \\
\hline
\end{tabular}



on Amaranthus hybridus growth and yield

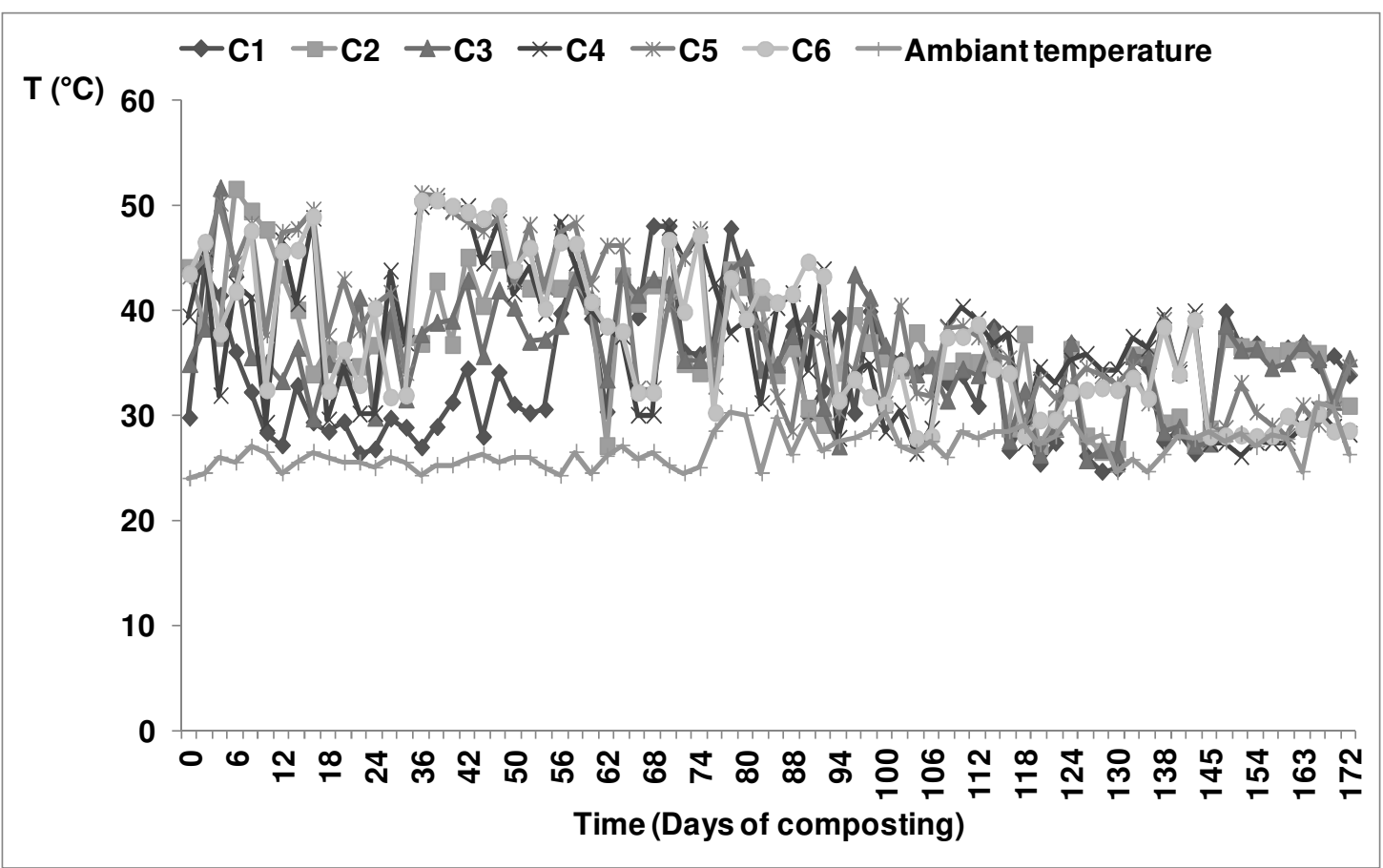

Figure 1: Temperature changes during Compositing process

Table 2: Composts physico-chemical parameters

\begin{tabular}{|c|c|c|c|c|c|c|}
\hline \multirow{2}{*}{$\begin{array}{l}\text { Composting method } \\
\text { Type of manure }\end{array}$} & \multicolumn{3}{|c|}{ Under shelter } & \multicolumn{3}{|c|}{ No shelter } \\
\hline & $\begin{array}{c}\text { No } \\
\text { Manure }\end{array}$ & $\begin{array}{l}\text { Poultry } \\
\text { Manure }\end{array}$ & $\begin{array}{l}\text { Cow } \\
\text { Dung }\end{array}$ & $\begin{array}{c}\text { No } \\
\text { Manure }\end{array}$ & $\begin{array}{l}\text { Poultry } \\
\text { Manure }\end{array}$ & $\begin{array}{l}\text { Cow } \\
\text { Dung }\end{array}$ \\
\hline $\mathrm{pH}$ & 6.8 & 6.3 & 6.8 & 5.8 & 6.4 & 6.4 \\
\hline Humidity & 49.7 & 63.28 & 56.61 & 71.04 & 49.39 & 51.08 \\
\hline Dry matter & 50.3 & 36.72 & 43.39 & 28.96 & 50.61 & 48.92 \\
\hline $\mathrm{N}$ & 1.67 & 1.76 & 0.78 & 0.76 & 1.64 & 0.74 \\
\hline C & 41.29 & 23.84 & 30.12 & 41.27 & 36.14 & 33 \\
\hline$P$ & 0.32 & 1.44 & 0.11 & 0.25 & 1.09 & 0.44 \\
\hline K & 1.84 & 1.02 & 0.9 & 1.24 & 1.14 & 2.08 \\
\hline $\mathrm{Ca}$ & 7.87 & 14.14 & 10.36 & 4.82 & 12.92 & 11.4 \\
\hline $\mathrm{Mg}$ & 4.91 & 3.72 & 4.42 & 4.11 & 2.88 & 4.28 \\
\hline
\end{tabular}

Effect of composting method, type of manure and compost rate application on Amaranthus hybridus growth: The analyses of all trials (Time*trials) results show a very significant $(p<0.0001)$ difference among the trials. The interaction Time ${ }^{*}$ trials ${ }^{*}$ composting method, Time*trials*compost rate were not significant for all parameters (Table 3 ). Only Time*trials*type of manure were very significant $(p<0.001)$. Therefore, the difference among trials was due to the type of manure applied. However when all the trials were considered as one, there was no significant difference among the repetitions. The leaf number, height and stem girth of Amaranthus hybridus increased very significantly $(p<0.00001)$ within the Weeks After Transplanting (WAT) and their values were less than 70,36 and 12 respectively. There was no significant difference $(p<0.05)$ in Amaranthus hibridus growth (leaf number, height and stem girth) when compost used was made under shelter or not (Time*composting method) (Table 3). However, the type of manure incorporated in POMW composting affected significantly $(\mathrm{p}<0.05)$ Amaranthus hybridus height and stem girth. At the end of 1 WAT, poultry manure increased plant height at $5.54 \%, 10.2 \%$ and $5.43 \%$ respectively at 2, 3 and 4 WAT. At the same period the use of the poultry manure increased plant stem girth at $8.57 \%, 9.7 \%, 6.16 \%$ respectively.. This compost with cow dung increased plant height at $8.57 \%, 9.7 \%, 6.16 \%$ and stem girth at $7.71 \%, 5.19 \%, 4.68 \%$ respectively at 2,3 


\section{Koura et al. J. Appl. Biosci. Effect of composting of palm oil mill wastes and cow dung or poultry manure on Amaranthus hybridus growth and yield}

and 4WAT. Cow dung increased significantly more Amaranthus hybridus height than poultry manure. The effect of type of manure added to palm oil mill wastes varied significantly $(p<0.05)$ within the composting method. The difference among composts for their effect on Amaranthus hybridus growth begun at 1WAT and was remarkable at 2 WAT (Figure 2). At 2WAT, composts C3, $\mathrm{C} 4$ and $\mathrm{C} 5$ improve more leaf number evolution than the others composts. At the same time, composts $\mathrm{C} 3, \mathrm{C} 5$ and C6 improve more plant height and stem girth than the others composts. After the 3 WAT, compost C5 showed itself more efficient to increase Amaranthus hybridus growth than the others composts. The compost application affects significantly $(p<0.05)$ Amaranthus hybridus growth (leaf number, height and stem girth) (Table 3). There are no difference among effects of $5 t / h a$ and10t/ha compost rate application (Figure 3). Compost need to be applied at 20t/ha at least but this rate is low to allow great leaves number and stem girth improve. No difference was noticed between $0 t /$ ha and $20 t /$ ha compost rate application effect on plant height. The effect of compost rate varied within composting method (Time* composting method ${ }^{*}$ rate) for leaves number and stem girth and within the type of manure use (Time*type of treatment ${ }^{\star}$ rate) for stem girth (Table 3). Compost made under shelter or not needs to be applied at more than 20t/ha for maximum leaf number and stem girth (Figures 3).

Table 3. Effect of composting method, type of manure and compost rate on Amaranthus hybridus growth

\begin{tabular}{|c|c|c|c|c|}
\hline \multirow{2}{*}{ Source } & \multirow{2}{*}{$D D L$} & \multicolumn{3}{|c|}{ F value (signification) } \\
\hline & & Leaf number & Height & Stem girth \\
\hline Time & 4 & $2086.71^{* * * *}$ & $4300.13^{\star * \star *}$ & $3674.22^{* * * *}$ \\
\hline Time*Essai & 8 & $24.10^{\star * * *}$ & $42.37^{\star * \star *}$ & $11.72^{\star * * *}$ \\
\hline Time* $B$ (Essai) & 36 & 1.10 & 0.92 & 1.01 \\
\hline Time*MC & 4 & 2.01 & 2.37 & 0.45 \\
\hline Time $^{*} \mathrm{TF}$ & 8 & 0.81 & $2.37^{*}$ & $2.17^{*}$ \\
\hline $\operatorname{Time}^{*} D$ & 12 & $2.11^{*}$ & $6.56^{\star \star * *}$ & $4.48^{\star * * *}$ \\
\hline Time $^{*}$ Essai*MC & 8 & 1.69 & $5.69^{\star *}$ & 0.65 \\
\hline Time $^{\star}$ Essai*TF & 16 & $3.79^{* *}$ & $7.45^{\star \star * *}$ & $4.28^{* \star * *}$ \\
\hline Time $^{*}$ Essai* $D$ & 24 & 0.40 & 1.41 & 0.98 \\
\hline Time*MC*TF & 8 & $4.10^{\star * *}$ & $2.52^{*}$ & $2.51^{*}$ \\
\hline $\operatorname{Time}^{*} M C^{*} D$ & 12 & $2.58^{\star *}$ & 1.74 & $2.05^{*}$ \\
\hline Time $^{*} T F^{*} D$ & 24 & 1.10 & 1.43 & $1.72^{*}$ \\
\hline Time $^{*} B^{*} M C$ (Essai) & 36 & 0.85 & 0.66 & 0.81 \\
\hline Time $^{*} B^{*} T F$ (Essai) & 72 & 1.23 & 1.12 & 1.08 \\
\hline Time $^{*} B^{*} D$ (Essai) & 108 & 0.63 & 0.60 & 0.68 \\
\hline Time* $B^{*} M C^{*} T F$ (Essai) & 88 & 0.68 & 1.16 & 1.04 \\
\hline Time ${ }^{*} B^{*} M C^{*} D$ (Essai) & 132 & 0.69 & 0.47 & 0.66 \\
\hline Time ${ }^{*} B^{*} T F^{*} D$ (Essai) & 264 & 0.65 & 0.97 & 0.81 \\
\hline Time* $M C^{*} T F^{*} D$ & 24 & 0.81 & 1.10 & 1.23 \\
\hline Time* $B^{*} M C^{*} T F^{*} D$ (Essai) & 264 & 1.06 & 1.00 & 0.90 \\
\hline
\end{tabular}






Figure 2: Effect of different composts on Amaranthus hybridus leaves number, height and stem girth
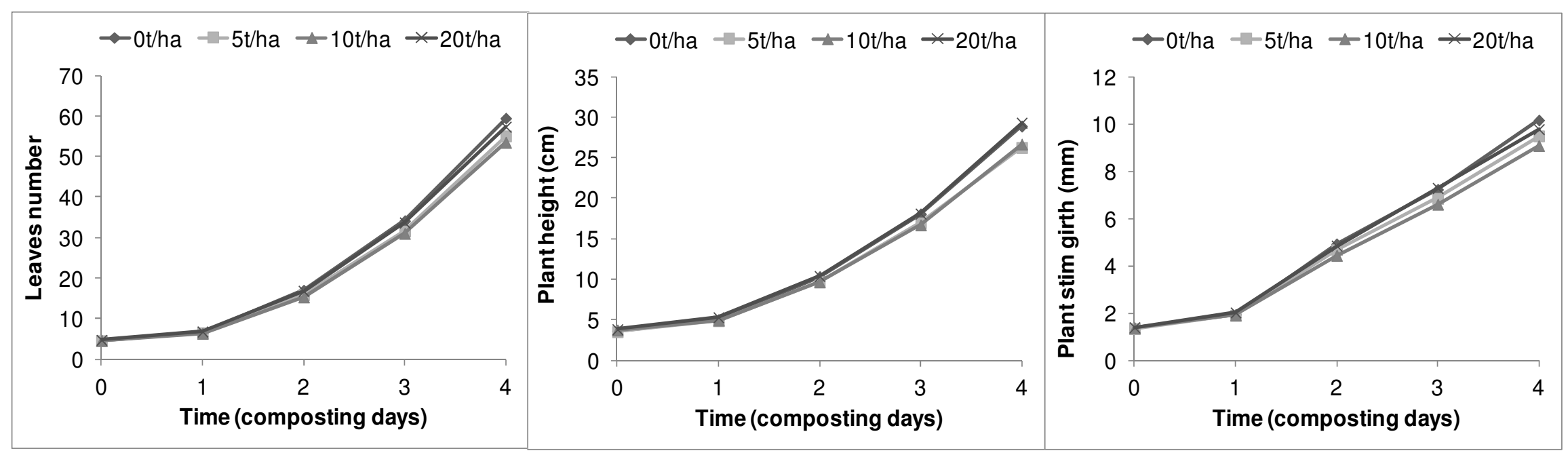

Figure 3: Effect of compost rate on Amaranthus hybridus leaves number, height and stem girth 


\section{Koura et al. J. Appl. Biosci. Effect of composting of palm oil mill wastes and cow dung or poultry manure}

on Amaranthus hybridus growth and yield

Effect of composting method, type of manure and compost rate application on Amaranthus hybridus yield: Type of manure incorporate in palm oil mill wastes and compost rate application do not affect significantly $(p<0.05)$ Amaranthus hybridus marketable yields (Table.4). Compost made under shelter ( $\mathrm{C} 4$ to $\mathrm{C} 6)$ gave in average 19.4 tha that was superior to yield obtain when compost made in opened system ( $\mathrm{C} 1$ to $\mathrm{C} 3$ ) were used. The use of compost with poultry manure ( $\mathrm{C} 2$ and C5) $(19.2 / \mathrm{ha})$ induced more marketable yield than compost made without manure (C1 and C4) (18.4t/ha) that induced more marketable yield than compost made with cow dung (C3 and C6) (17.8t/ha). The effect of compost application was registered when it was applied at $20 \mathrm{t} / \mathrm{ha}$ rate $(20.1 \mathrm{t} / \mathrm{ha})$.

Table 4: Effect of composting method, type of manure and compost rate on Amaranthus hybridus yield

\begin{tabular}{|c|c|}
\hline Traitement & Marketable yield (t/ha) \\
\hline \multicolumn{2}{|c|}{ Composting method (A) } \\
\hline No shelter & 17.5 \\
\hline Under shelter & 19.4 \\
\hline $\mathrm{LSD}_{0.05}$ & 0.5 \\
\hline \multicolumn{2}{|c|}{ Type of manure (B) } \\
\hline No manure & 18.4 \\
\hline Poultry manure & 19.2 \\
\hline Cow dung. & 17.8 \\
\hline LSD $_{0.05}$ & 0.29 \\
\hline \multicolumn{2}{|c|}{ Compost rate application (C) } \\
\hline 0t/ha & 17.9 \\
\hline $5 t / h a$ & 17.5 \\
\hline 10t/ha & 18.3 \\
\hline 20t/ha & 20.1 \\
\hline $\mathrm{LSD}_{0.05}$ & 0.12 \\
\hline$A^{*} B$ & 0.46 \\
\hline$A^{*} C$ & 0.32 \\
\hline $\mathrm{B}^{*} \mathrm{C}$ & 0.38 \\
\hline$A^{*} B^{*} C$ & 0.84 \\
\hline
\end{tabular}




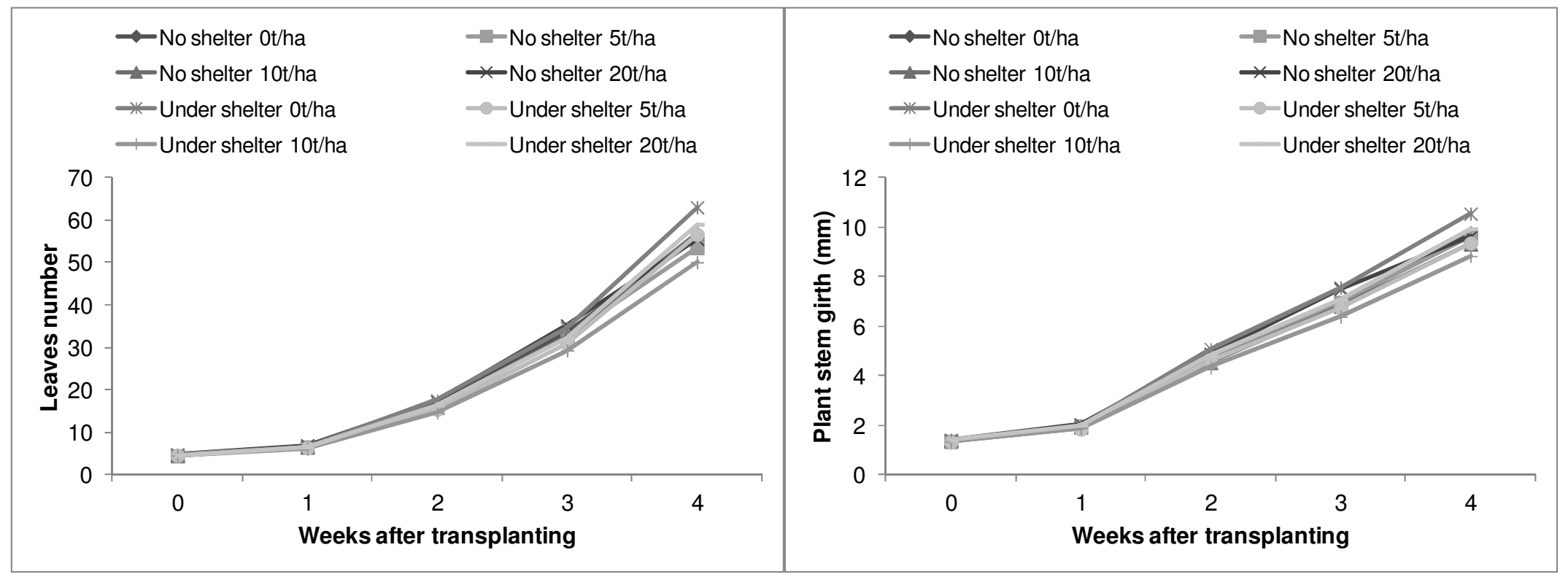

Figure 4: Effect of the interaction of composting method and compost rate application on Amaranthus hybridus leaves number and stem girth 


\section{DISCUSSION}

Composting under shelter had increased Amaranthus hybridus marketable yield This means that farmers who want to manetable yield. This means that farmers who want to mak palmean arean mast composts made under by leaching and allowed beter mineralizalion. According to Eghball et al. (1007), Venglovsky and Grecerova to rin and this could affect compost qually. White to rain and this could affect compost qually. While composts made without manure (C1 and C4) gave the lowest Amaranthus hybidus growh, compost made with manure allowed best Amaranthus hybridus growth. This can be explained by the low mineralization of POMWS composting without manure. Moreover, according to Rao (1991), soil could be enriched by application of highe amount of organic materials that tends to decompose large amounts of nitrogen into the soil before planting each fresh crop to boost yield. Also Xu et al. (2005) share the same ideas and adviced the use of higher levels of organic manures. The use of compost with manure or not improves Amaranthus hybridus yield. This was explained by the richness of palm oil mill wastes in nitrogen and

\section{CONCLUSION}

Palm oil mill wastes can be used to enhance Amaranthus hybridus growth and improve crop yield through composting. The use of manure in this composting process and the control of this degradetion by covering the compost heap improved growth and yield of this

\section{REFERENCES}

Assogba-Komlan F and Chabi B I, 2001. Influence de deux types de déjections animales sur le rendement d'une variété de tomate. Actes de rendement d'une variete de tomate. Actes de
l'Atelier Scientifique, Parakou (13-14 Mars 2001), 135-147.

Assogba-Komlan F, Anihouvi P, Achigan E, Sikirou R Boko A, Adje C, Ahle V, Vodouhe R, Assa A 2007. Pratiques culturales et teneur en élements anti nutritionnels (nitrates et pesticides) du Solanum macrocarpum au sud du Bénin. African journal of food agriculture nutrition and development. 7 (4). 21pp

Adegbola YP, Sodjinou E, Akoha S, 2009. Diagnostic des contraintes à la production cotonnière au Benin Institut National de Recherches Agricole-Bénin (INRAB), Cotonou, 14pp.

Adewale MT, 2011. Composting as a sustainable waste management technique in developing countries. Journal of Environmental Science and potassium. Despite its richness, it is important to add manure for its fast and best mineralization. Contray results were obtained by Bioou (2009) who found that compost made with poulty manure was the best for compost made with poultry manure was the best for between effect of poulty between effect of poultry manure and cow dung on Amaranthus growh and yield. According to Oworu et al. poutry mung application. poulty manure application. Masarirambi et al. (2012) show that poultry manure application improves lettuce growth. Ainiki et al. (2012) and Akparobi (2009) show that Farmyard manure application improves Amaranthus growth. The results obtain show that Amaranthus growth and yield increase significantly with increase of rate of compost application. However, 20t/ha of compost application was low to boost a significant effect of compost application Similar results was obtained by Akparobi (2009) who use farmyard manure at 15t/ha, 25t/ha and 35tha. This study confirms the works of Biao (2009) on the importance to increase organic fertilize rate application to more than 20tha as recommended by Assogba komlan et al. (2007) for vegetables in Benin. vegetable. Furthers studies must be done with increasing
the rate of manure used to make the compost, use of another type of manure (sheep droppings, rabbitmanure, f these composts on other vegetables growth and yield.

Technology 4: 93-102

BAILEY JM, 1992. The leaves we eat. CTA/South Pacific Commission Handbook 31, Noumea, New Coledonia: 97pp. ISBN: 982-203-245-5

Embrandiri A, Ibrahim HM, Singh PR, 2013. Palm oil mills wastes utilization; sustainability in the Malaysian context. International Journal of Scientific and Research Publications 7pp. ISSN 2250-3153

Habib MAB, Yusoff FM, Phang SM KJ, Mohamed S. 1997. Nutritional values of chironomid larvae grown in palm oil mill effluent and algal culture. Aquaculture 158: 95-105.

wara Al; Ewa EE; Ogundele FO; Adeyemi JA; Otu CA 2011. Ameliorating effects of palm oil mill effluent on the physical and chemical properties of soil in Ugep, Cross River State, SouthSouthern Nigeria. International Journal of Applied Science and Technology 1(5): 106-112. 
Koura et al. J. Appl. Biosci. Effect of composting of palm oil mill wastes and cow dung or poultry manure on Amaranthus hybridus growth and yield

Kolade O.O., Coker A.O., Sridhar M.K.C., Adeoye G.O

2012. Palm kernel waste management through

composting and crop production. Journal of

Environmental Health Research. 5 (2), 81-85.

Makinde EA, Ayeni LS, Ojeniyi SO, Odedina JN, 2010 Effect of organic, organomineral and NPK fertilizer on nutritional quality of Amaranthus in Lagos, Nigeria. Researcher. 2(12): $32-36$ Avallable$$
\text { http://www.sciencepub.net/researcher }
$$
edible plants in Nhema communal area Midlands province, Zimbabwe. Ecology of Food

and Nutrition 50: 506-525

Muhrizal S, Shamshuddin J, Fauziah I, Husni MAH, 2006. Changes in iron-poor acid sulfate soil upon submergence Geoderma 131:110-122.

Schuchardt F, Wulfert K, Darnoko D, Herawan T, 2008. Effect of new palm oil mill processes on the EFB and POME utilization. Journal of Oil Palm Research Special Issue October 2008:115-126 Suhaimi M, Ong HK, 2001. Composting Empty Fruit Bunches of Oil Palm. FFTC Publication. Malaysian Agric. Res. Dev. inst. Malaysia 2001 